\title{
Corrigendum
}

\section{Corrigendum to "Insights into methane dynamics from analysis of authigenic carbonates and chemosynthetic mussels at newly-discovered Atlantic Margin seeps" [Earth Planet. Sci. Lett. 449 (2016) 332-344]}

\author{
N.G. Prouty ${ }^{\mathrm{a}, *}$, D. Sahy ${ }^{\mathrm{b}}$, C.D. Ruppel ${ }^{\mathrm{c}}$, E.B. Roark ${ }^{\mathrm{d}}$, D. Condon ${ }^{\mathrm{b}}$, S. Brooke ${ }^{\mathrm{e}}$, S.W. Ross ${ }^{\mathrm{f}}$, \\ A.W.J. Demopoulos ${ }^{g}$ \\ a US Geological Survey, Pacific Coastal and Marine Science Center, 400 Natural Bridges Drive Santa Cruz, CA 95060, United States \\ b NERC Isotope Geosciences Laboratory, British Geological Survey, Nicker Hill, Keyworth NG12 5GG, UK \\ c US Geological Survey, Woods Hole Coastal and Marine Science Center, Woods Hole, MA 02543, United States \\ d Department of Geography, Texas AEM University, College Station, TX 77843, United States \\ e Florida State University, Coastal and Marine Laboratory, 3618 Coastal Highway, 98 St. Teresa, FL 32358, United States \\ ${ }^{\mathrm{f}}$ University of North Carolina-Wilmington, Center for Marine Science, 5600 Marvin Moss Ln, Wilmington, NC 28409, United States \\ g US Geological Survey, Wetland and Aquatic Research Center, 7920 NW 71st St., Gainesville, FL 32653, United States
}

\section{A R T I C L E I N F O}

\section{Article history:}

Received 21 July 2017

Accepted 23 July 2017

Available online 3 August 2017

Editor: M. Frank

The authors have discovered a calculation error in reporting the assumed $\Delta^{14} \mathrm{C}$ signature of methane. According to Pohlman et al. (2009), the lower limit of gas-hydrate bearing methane is 0.12 pMC, equivalent to $-998.8 \%,{ }^{1}$ indicating that $\sim 9 \%$ of the carbon signature for shell calcification at the Norfolk Seep site is derived from fossil carbon.

\section{References}

Pohlman, J.W., Kaneko, M., Heuer, V.B., Coffin, R.B., Whiticar, M., 2009. Methane sources and production in the northern Cascadia margin gas hydrate system. Earth Planet. Sci. Lett. 287, 504-512.
Prouty, N.G., Sahy, D., Ruppel, C.D., Roark, E.B., Condon, D., Brooke, S., Ross, S.W., Demopoulos, A.W.J., 2016. Insights into methane dynamics from analysis of authigenic carbonates and chemosynthetic mussels at newly-discovered Atlantic Margin seeps. Earth Planet. Sci. Lett. http://dx.doi.org/10.1016/j.epsl.2016.05.023.

DOI of original article: http://dx.doi.org/10.1016/j.epsl.2016.05.023.

* Corresponding author.

E-mail address: nprouty@usgs.gov (N.G. Prouty).

1 Originally reported in Prouty et al. (2016) as $-880 \%$. 